\title{
Properties of one-layer experimental particleboards from willow (Salix viminalis) and industrial wood particles
}

\author{
Krzysztof Warmbier • Arnold Wilczyński • \\ Leszek Danecki
}

Received: 24 May 2012/ Published online: 30 November 2012

(C) The Author(s) 2012. This article is published with open access at Springerlink.com

\begin{abstract}
The objective of this study was to investigate some mechanical and physical properties of one-layer particleboards made from various willow (Salix viminalis) and industrial pine wood particle mixtures bonded with urea formaldehyde resin. Modulus of elasticity and modulus of rupture decreased, whereas internal bond and screw holding strengths increased with increasing willow particle content. The decrease in bending properties was rather small; these properties of particleboards containing $50 \%$ willow particles were on average smaller by about $10 \%$ than particleboards containing only industrial wood particles. Increasing the willow particle content resulted in improved water absorption and thickness swelling. The willow Salix viminalis can be considered as a substitute for pine wood for manufacturing of particleboards.
\end{abstract}

\section{Eigenschaften einschichtiger Versuchsspanplatten aus Weidenspänen (Salix viminalis) und industriellen Holzspänen}

Zusammenfassung Ziel dieser Studie war es, einige mechanische und physikalische Eigenschaften einschichtiger Spanplatten zu untersuchen, die aus verschiedenen Mischungen von Weidenspänen (Salix viminalis) und industriellen Kiefernholzspänen hergestellt und mit Harnstoffharz verklebt wurden. Der Elastizitätsmodul und die Biegefestigkeit nahmen mit zunehmendem Anteil an

\footnotetext{
K. Warmbier $(\bowtie) \cdot$ A. Wilczyński

Institute of Technology, Kazimierz Wielki University,

Bydgoszcz, Poland

e-mail: warm@ukw.edu.pl

L. Danecki

Research and Development Centre for Wood-Based Panels Industry, Czarna Woda, Poland
}

Weidenspänen ab, wohingegen die Querzugfestigkeit und der Schraubenausziehwiderstand zunahmen. Die Abnahme der Biegeeigenschaften war relativ gering; bei Spanplatten mit $50 \%$ Weidenspäneanteil waren diese Eigenschaften um durchschnittlich $10 \%$ geringer als bei Spanplatten aus ausschließlich industriellen Holzspänen. Eine Erhöhung des Weidenspäneanteils führte zu einer geringeren Wasseraufnahme und Dickenquellung. Salix viminalis kann als Ersatz für Kiefernholz zur Herstellung von Spanplatten in Betracht gezogen werden.

\section{Introduction}

Particleboards are the most widely used wood composite. Continually increasing particleboard production in many countries, including Poland, and shortage of forest resources make it necessary to search for alternative lignocellulosic materials in particleboard manufacturing. One possible raw material can be fast growing shrubs. Such a shrub being cultivated for energy purposes is the willow Salix viminalis. In Poland it is cultivated in about 800 short-rotation plantations on an area of 6,160 ha (Grzybek 2011).

The suitability of the willow Salix viminalis for particleboard manufacturing has been the subject of only a few studies. Sean and Labrecque (2006) investigated the usefulness of Quebec clones of the willow Salix viminalis. They studied three-layer particleboards with face and core layers made using 10-30\% willow, and concluded that the mechanical properties of particleboards with up to $30 \%$ willow particles were generally greater than those of particleboards made from industrial wood particles. Frackowiak et al. (2008) stated that the replacement of $25 \%$ of pine particles by willow ones in the core layer of three- 
layer particleboards improved the mechanical properties in bending. Warmbier et al. (2010) found that the mechanical properties of three-layer particleboards with the core layer made of willow particles were smaller compared to those with the core layer made of industrial pine particles. The results of the presented studies are inconsistent. The first two studies indicate that willow particles as a substitute for industrial particles improve the mechanical properties of three-layer particleboards while the third study indicates that those particles worsen them.

A typical commercial particleboard is a three-layer board which consists of a core layer and two face layers. The structures and properties of these layers differ markedly. The face layers, made from smaller particles with a higher resin content, have a greater compaction ratio and density, and in consequence better mechanical properties. Face layers are crucially important in transferring load in elements made from particleboard. When these elements are loaded in bending, face layers transfer more than twothirds of a bending moment. It is assumed that willow particles as a substitute for industrial wood particles will be used for manufacturing the core layer of three-layer particleboards only. In such a case a comparative study of the properties of a three-layer particleboard with the core layer from willow and industrial particles would be inefficient. Therefore, it was decided to investigate a one-layer particleboard as a simulation of the core layer of a three-layer particleboard.

The objective of this study was to evaluate some mechanical and physical properties of one-layer particleboard made from the willow Salix viminalis and industrial wood particles as affected by various willow particle contents and resin contents.

\section{Materials and methods}

Raw materials for this study consisted of willow (Salix viminalis) stems and industrial wood particles. Three-yearold stems were collected from the Miescisko plantation, located in north-western Poland in the Wielkopolska Region. The stem diameter at the base ranged between 28 and $35 \mathrm{~mm}$, while the height ranged between 4.9 and $5.3 \mathrm{~m}$. Bark percentage was about $15 \%$ of stem weight. The stems were stored for air-drying to a moisture content of about $12 \%$, then chipped in a hammer-mill. Industrial pine particles used for manufacturing the core layer of three-layer particleboards were supplied by Pfleiderer Prospan Wieruszow (Poland). Both willow and pine particles were then screened by an analytical sieve shaker using 4 and $1 \mathrm{~mm}$ sieves. Particles that passed through the $4 \mathrm{~mm}$ sieve and remained on the $1 \mathrm{~mm}$ sieve were used as furnishes for one-layer experimental particleboards that
Table 1 Manufacturing parameters

Tab. 1 Herstellparameter

\begin{tabular}{ll}
\hline Board thickness & $10 \mathrm{~mm}$ \\
Board dimensions & $40 \mathrm{~cm} \times 40 \mathrm{~cm}$ \\
Target board density & $600 \mathrm{~kg} / \mathrm{m}^{3}$ \\
Press temperature & $180{ }^{\circ} \mathrm{C}$ \\
Maximum pressure & $2.5 \mathrm{MPa}$ \\
Press closing time & $25 \mathrm{~s}$ \\
Pressing time & $3 \mathrm{~min}$ \\
\hline
\end{tabular}

simulated the core layer of three-layer particleboard. The particles were dried to achieve moisture content of less than $3 \%$.

Urea-formaldehyde (UF) resin was used as a binder. Two levels of resin content, 8 and $10 \%$, were assumed. The ratio of willow to industrial wood particles was the next factor. Six values of this ratio, $0,12.5,25,50,75$ and $100 \%$, were assumed. The board manufacturing parameters are listed in Table 1. Four experimental boards were produced for each board type.

Prior to testing all the boards were stored under controlled conditions ( $50 \%$ relative humidity and $20{ }^{\circ} \mathrm{C}$ ) for 2 weeks. Test specimens were cut from the boards to determine the following mechanical and physical properties according to appropriate EN standards: modulus of elasticity (MOE) and modulus of rupture (MOR) (EN 310:1993), internal bond (IB) (EN 319:1993), screwholding strength (SHS) (EN 13446:2002) by using screws with a diameter of $3.5 \mathrm{~mm}$, length of $45 \mathrm{~mm}$ and a hole diameter of $2.5 \mathrm{~mm}$, water absorption (WA) and thickness swelling (TS) after $24 \mathrm{~h}$ (EN 317:1993). Twenty replicates were run for each test.

\section{Results and discussion}

The mechanical and physical properties of tested particleboards are given in Table 2 . The mechanical properties in bending, MOE and MOR, decreased gradually with increasing the willow particle content from 0 to $100 \%$. MOE and MOR of particleboards made from $100 \%$ willow were smaller by 22.1 and $15.3 \%$, respectively, than those of particleboards made from $100 \%$ industrial wood particles when the resin content was $10 \%$, and smaller by $19.4 \%$ and $7.1 \%$, respectively, when this content was $8 \%$. MOE and MOR of particleboards containing $50 \%$ willow particles were on average smaller by 12.5 and $6.2 \%$, respectively, than those of particleboards containing only industrial wood particles. The decrease in the mechanical properties in bending with increasing the willow particle content was partly caused by willow particle geometry. The slenderness of these particles was much 
Table 2 Properties of one-layer experimental particleboards

Tab. 2 Eigenschaften einschichtiger Versuchsspanplatten

\begin{tabular}{|c|c|c|c|c|c|c|c|}
\hline $\begin{array}{l}\text { Willow content } \\
(\%)\end{array}$ & $\begin{array}{l}\text { Resin content } \\
(\%)\end{array}$ & MOE (GPa) & MOR (MPa) & IB (MPa) & SHS (MPa) & WA $(\%)$ & TS $(\%)$ \\
\hline 0 & 8 & $1.71 \mathrm{~cd}(0.24)$ & $9.9 \mathrm{ab}(1.5)$ & 0.55 a $(0.08)$ & $16.2 \mathrm{a}(2.8)$ & 103.0 c (7.8) & $32.2 \mathrm{~d}(4.5)$ \\
\hline 50 & & $1.47 \mathrm{ab}(0.18)$ & 9.4 a (1.2) & $0.64 \mathrm{ab}(0.09)$ & $18.1 \mathrm{ab}(2.9)$ & 101.7 c (6.9) & $31.0 \mathrm{~cd}(4.1)$ \\
\hline 100 & & 1.38 a $(0.17)$ & $9.2 \mathrm{a}(1.1)$ & 0.68 bcd (0.09) & $20.8 \mathrm{bc}(2.4)$ & $94.1 \mathrm{~b}(6.3)$ & $28.5 \mathrm{bcd}(3.3)$ \\
\hline 0 & 10 & $1.99 \mathrm{f}(0.26)$ & $12.4 \mathrm{e}(1.5)$ & $0.63 \mathrm{ab}(0.09)$ & $21.9 \mathrm{~cd}(1.9)$ & $89.4 \mathrm{ab}(6.8)$ & $27.3 \mathrm{abc}(2.6)$ \\
\hline 12.5 & & 1.93 ef $(0.22)$ & 11.9 de (1.4) & $0.65 \mathrm{abc}(0.08)$ & $22.0 \mathrm{~cd}(1.3)$ & $91.1 \mathrm{ab}(7.3)$ & $26.8 \mathrm{ab}(3.7)$ \\
\hline 25 & & $1.83 \operatorname{def}(0.20)$ & $11.6 \mathrm{cde}(1.2)$ & 0.67 bc (0.09) & $22.9 \mathrm{~cd}(2.0)$ & $91.8 \mathrm{ab}(6.6)$ & $28.6 \mathrm{bcd}(3.7)$ \\
\hline 50 & & 1.77 cde $(0.15)$ & $11.5 \mathrm{cde}(1.2)$ & 0.68 bcd (0.09) & $23.1 \mathrm{~cd}(2.1)$ & $88.5 \mathrm{ab}(6.1)$ & $27.5 \mathrm{abc}(3.4)$ \\
\hline 75 & & $1.63 \mathrm{bc}(0.14)$ & $10.7 \mathrm{bcd}(1.1)$ & $0.73 \mathrm{~cd}(0.09)$ & $25.0 \mathrm{~d}(2.5)$ & $86.7 \mathrm{ab}(5.8)$ & $26.7 \mathrm{ab}(3.1)$ \\
\hline 100 & & $1.55 \mathrm{abc}(0.13)$ & $10.5 \mathrm{abc}(1.0)$ & $0.75 \mathrm{~d}(0.09)$ & $23.9 \mathrm{~cd} \mathrm{(2.2)}$ & 84.5 a $(5.5)$ & $24.4 \mathrm{a}(2.8)$ \\
\hline
\end{tabular}

Mean values with the same letter for given property are not significantly different at the $5 \%$ level (Tukey test)

Standard deviations are in parentheses

MOE modulus of elasticity, MOR modulus of rupture, IB internal bond, SHS screw-holding strength, WA water absorption, TS thickness swelling

smaller in comparison to industrial wood particles. Another cause of the decrease in MOE and MOR was probably the usage of bark which was considerably greater for willow than for industrial wood particles. The negative effect of bark on MOE and MOR of particleboards with 22 and $30 \%$ of the willow Salix viminalis was observed by Sean and Labrecque (2006).

The two other mechanical properties of the tested particleboards, IB and SHS, contrary to MOE and MOR, increased with increasing the willow particle content from 0 to $100 \%$. IB and SHS of particleboards made from $100 \%$ willow were greater by 19.0 and $9.2 \%$, respectively, than those of particleboards made from $100 \%$ industrial wood particles when the resin content was $10 \%$, and greater by 23.6 and $28.3 \%$, respectively, when this content was $8 \%$. IB and SHS of particleboards containing $50 \%$ willow particles were on average greater by 12.2 and $8.4 \%$, respectively, than those of particleboards containing only industrial wood particles. The increase in IB and SHS with increasing willow particle content was probably caused by the willow particle width and thickness which were greater in comparison to industrial wood particles. The increase in particleboard IB when the content of willow increased from 10 to $30 \%$ was also observed by Sean and Labrecque (2006).

In general, the physical properties, WA and TS, decreased with increasing the willow particle content from 0 to $100 \%$. WA and TS of particleboards made from $100 \%$ willow were smaller by 5.5 and $10.6 \%$, respectively, than those of particleboards made from $100 \%$ industrial wood particles when the resin content was $10 \%$, and smaller by 8.6 and $11.5 \%$, respectively, when this content was $8 \%$. WA and TS of particleboards containing $50 \%$ willow particles were on average smaller by 1.2 and
$1.5 \%$, respectively, than those of particleboards containing only industrial wood particles.

Increasing the resin content from 8 to $10 \%$ resulted in improving the particleboard properties. MOE, MOR, IB and SHS of particleboards bonded with $10 \%$ resin were on average greater by $16.5,20.6,10.4$ and $26.3 \%$, and WA and TS of those particleboards were on average smaller by 12.1 and $13.6 \%$, respectively. It is worth mentioning that IB of all of the tested boards met the requirements of the EN 312 (2003) standard for particleboards of type P2, P4 and P6 (boards for use in dry conditions). Moreover, MOE of boards bonded with the $10 \%$ resin content and willow content not greater than $50 \%$ met the requirement of this standard for particleboards of type P2.

\section{Conclusion}

One-layer experimental particleboards were manufactured using particles made from the willow Salix viminalis as a substitute for industrial particles made from pine wood. Since these particleboards were to simulate the core layer of typical three-layer particleboards, they were made of coarse particles of the fraction $4>\mathrm{F}>1 \mathrm{~mm}$. The content of willow particles in particleboards affected significantly all of the determined mechanical (MOE, MOR, IB and SHS) and physical (WA and TS) properties. MOE, MOR, WA and TS decreased, whereas IB and SHS increased with increasing the willow particle content from 0 to $100 \%$. The decrease in MOE and MOR was rather small; the moduli of the particleboards containing $50 \%$ willow particles were on average smaller by 12.5 and $6.2 \%$, respectively, than particleboards containing only industrial wood particles. The willow Salix viminalis can be 
considered as a substitute for pine wood for manufacturing the core layer of three-layer particleboards.

Acknowledgments This research project was supported by the Polish Ministry of Science and Higher Education, grant number $\mathrm{N}$ N309 133535.

Open Access This article is distributed under the terms of the Creative Commons Attribution License which permits any use, distribution, and reproduction in any medium, provided the original author(s) and the source are credited.

\section{References}

EN 13446 (2002) Wood-based panels-Determination of withdrawal capacity of fasteners. European Committee for Standardization, Brussels-Belgium

EN 310 (1993) Wood-based panels-Determination of modulus of elasticity in bending and of bending strength. European Committee for Standardization, Brussels-Belgium
EN 317 (1993) Particleboards and fiberboards-Determination of swelling in thickness after immersion in water. European Committee for Standardization, Brussels-Belgium

EN 319 (1993) Particleboards and fiberboards-Determination of tensile strength perpendicular to the plane of the board. European Committee for Standardization, Brussels-Belgium

EN 312 (2003) Particleboards-Specifications. European Committee for Standardization, Brussels-Belgium

Frackowiak I, Fuczek D, Kowaluk G (2008) Impact of different lignocellulosic materials used in core of particleboard on modulus of elasticity and bending strength. Drewno Wood 51:5-13

Grzybek A (2011) Biomass for the production of energy (in Polish). Instytut Technologiczno-Przyrodniczy, Poznań, http://www. czystaenergia.pl/pdf/farma2011/2_grzybek_itp.pdf

Sean ST, Labrecque M (2006) Use of short-rotation coppice willow clones of Salix viminalis as furnish in panel production. For Prod J56(9):47-52

Warmbier K, Wilczyński A, Danecki L (2010) Particle size dependent properties of three-layer particleboards with the core layer made from willow (Salix viminalis). Annals of Warsaw University of Life Sciences. For Wood Technol 71:405-409 